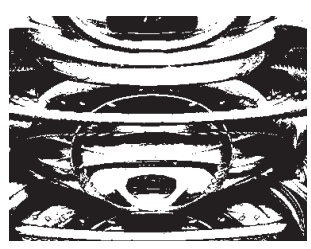

\title{
ULOGA NEKIH VRŠNJAČKIH I ŠKOLSKIH VARIJABLI U PREDVIĐANJU VRŠNJAČKOGA NASILNOG PONAŠANJA
}

Tena VELKI

Učiteljski fakultet, Osijek

Gabrijela VRDOLJAK

Filozofski fakultet, Osijek

UDK: [37.06:364.271](497.5)

Izvorni znanstveni rad

Primljeno: 5. 11. 2012.

Cili je ovog istraživanja bio ispitati potencijalne vršnjačke i školske prediktore vršnjačkoga nasilnog ponašanja na hrvatskom uzorku djece osnovnoškolske dobi. Uz kontrolu spola, dobi i školskog uspieha, cili nam je bio provjeriti koji od odabranih vršnjačkih prediktora (broi prijatelia, socijalni status, prihvaćenost vršnjaka) i školskih prediktora (školska klima i sigurnost u školskom okruženju) predviđaju ukupno, verbalno i tjelesno vršnjačko nasilje te ukupnu, verbalnu i tjelesnu viktimizaciju. U istraživanju je sudjelovalo 262 učenika od 5. do 8. razreda osnovne škole. Učenici su ispunili Upitnik o nasilju među školskom djecom, Upitnik školske klime te sociometrijski postupak. Rezultati pokazuju kako odabrani prediktori najbolje objašnjavaju tjelesno vršnjačko nasilje $(31,9 \%)$ te verbalnu viktimizaciju (33\%). Uz kontrolu individualnih varijabli, broj prijatelja, socijalni status i školska klima pokazali su se značajnim prediktorima vršnjačkoga nasilja, dok su se broi prijatelia, socijalni status, prihvaćenost i školska klima pokazali značajnim prediktorima vršnjačke viktimizacije. Istraživanje upućuje na jak utjecaj vršnjačkih i školskih varijabli u predviđanju vršnjačkoga nasilja i viktimizacije. Ipak, značajan udio varijance vršnjačkoga nasilja i viktimizacije ostao je neobjašnjen, pa je preporuka za buduća istraživanja da i neke druge varijable, npr. obitelj i medije, ispita kao potencijalne prediktore.

Ključne riječi: vršnjačko nasilje, školski prediktori, vršnjački prediktori 
Vršnjačko zlostavljanje često se definira kao oblik agresivnoga ponašanja u kojem postoji nerazmjer moći između djeteta nasilnika i djeteta žrtve gdje nasilnik ima veću moć, a takvo ponašanje učestalo se ponavlja (Rigby, 2002). Olweus (1998) navodi kako vršnjačko zlostavljanje obilježavaju tri kriterija: (1) namjerno nanošenje štete drugoj osobi, (2) ponavljanje i trajanje neko vrijeme (3) te neravnoteža moći. U literaturi nije uvijek jasno operacionalizirano jesu li zadovoljeni svi kriteriji da bismo određeno ponašanje mogli svrstati u vršnjačko zlostavljanje (engl. bullying), stoga se vršnjačko zlostavljanje neopravdano često poistovjećuje s vršnjačkim nasiljem (engl. peer vio-

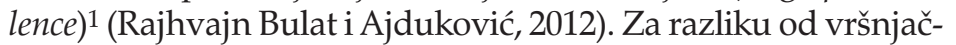
koga zlostavljanja, vršnjačko nasilje ne uključuje sve distinktivne karakteristike, odnosno najčešće ne ispituje odnos moći nasilnika i žrtve te namjeru počinjenoga nasilničkog ponašanja. Djeca uključena u problematiku vršnjačkoga zlostavljanja mogu se svrstati u tri kategorije: nasilnici i/ili zlostavljači - djeca koja samo provode nasilničko ponašanje nad vršnjacima, pasivne žrtve - djeca koja samo trpe nasilničko ponašanje te provokativne žrtve - djeca koja istodobno i čine i trpe nasilničko ponašanje. Djeca koja nisu uključena u ovu problematiku jesu djeca promatrači, koja iako ne sudjeluju izravno u nasilnom ponašanju, mogu imati negativne posljedice promatrajući takvo ponašanje (Olweus, 1998). Ova je skupina djeca ključna u prekidanju vršnjačkoga nasilja.

Istraživanja u svijetu (Cook, Williams, Guerra i Kim, 2010) pokazuju da je do 11 godina oko $16 \%$ počinitelja nasilja, oko $18 \%$ žrtava te oko $7 \%$ provokativnih žrtava, a od 12 do 14 godina oko $20 \%$ počinitelja nasilja, oko $26 \%$ žrtava i oko $10 \%$ provokativnih žrtava. Ranija istraživanja u Hrvatskoj na osnovnoškolskom uzrastu (Buljan Flander, Ćorić Špoljarić i Durman Marijanović, 2007; Profaca, Puhovski i Luca Mrđen, 2006) pokazala su da je nasilno oko $8 \%$ djece, $19 \%$ djece su žrtve te je oko $8 \%$ provokativnih žrtava. Novije istraživanje Sušac, Rimac i Ajduković (2012) na nacionalnom uzorku govori o prevalenciji od 2,3\% počinitelja nasilja, $14,4 \%$ žrtava i 7,7\% provokativnih žrtava (5. razred osnovne škole), koja raste s porastom dobi tako da u 7. razredu osnovne škole ima $6,5 \%$ počinitelja nasilja, 17,6\% žrtava i 16,4\% provokativnih žrtava. Slič-

$1 \mathrm{U}$ dalinjem tekstu termin međuvršnjačko zlostavlianje (engl. bullying) i međuvršnjačko nasilie (engl. peer violence) rabit će se onako kako su ih upotrijebili autori izvornih referenci. ni rezultati dobiveni su na uzorku osječke djece osnovnoškolske dobi, pri čemu je dobiveno oko $4 \%$ počinitelja nasilja, 30\% žrtava i 14\% provokativnih žrtava (Velki, 2012a).

Mnoga istraživanja bavila su se predviđanjem vršnjačkoga nasilja (Ahmed i Braithwaite, 2004; Barboza i sur., 2009), a najčešće su ispitivala individualne karakteristike (Barboza i sur., 2009), obitelj (Velki, 2012b), školu (Harel-Fisch i sur., 2011) 
DRUŠ. ISTRAŽ. ZAGREB GOD. 22 (2013), BR. 1 STR. 101-120

VELKI, T., VRDOLJAK, G.: ULOGA NEKIH... i vršnjake (Mouttapa, Valente, Gallaher, Rohrbach i Unger, 2004). Pri tome su dobiveni konzistentni rezultati kada su u pitanju individualne karakteristike kao što su spol i dob. Gotovo sva istraživanja pokazala su kako stariji dječaci iskazuju više nasilnoga ponašanja (Olweus, 1998; Velki, 2012a). Dječaci su tjelesno i verbalno nasilniji (Espelage, Bosworth i Simon, 2000; McDermott, 1996), a novija istraživanja pokazuju da kada su u pitanju relacijski i indirektni oblici nasilja, dječaci su podjednako nasilni, ako ne i malo više nasilni, od djevojčica (Olwues, 2010). Dječaci su i češće žrtve svih oblika vršnjačkoga nasilja (Olweus, 1998, 2010). Količina sveukupne agresije raste s porastom dobi (Buljan Flander i sur., 2007; Olweus, 1998; Velki, 2012b). Najviše nasilnoga ponašanja iskazuju učenici završnih razreda osnovnih škola, dok su žrtve češće mlađi učenici. I školski uspjeh pokazao se značajnim za predviđanje vršnjačkoga nasilja, pri čemu je slabiji školski uspjeh povezan $\mathrm{s}$ više nasilnoga ponašanja i viktimizacije (Dake, Price i Telljohann, 2003; Farrington, 1997; Profaca i sur., 2006).

Iako obitelj ima važnu ulogu u razvoju nasilnoga ponašanja u djece (Velki, 2012a), u adolescentskoj dobi sve veći utjecaj na ova neprilagođena ponašanja imaju vršnjaci s kojima se djeca druže i školski sustav u sklopu kojeg djeca provode većinu svojega vremena. Djeca se češće druže s vršnjacima koji imaju slične interese i reputaciju kao i oni sami (Pellegrini, Bartini i Brooks, 1999), pa tako agresivna djeca imaju više prijatelja koji vole kršiti pravila (Bagwell i Coie, 2004; Dijkstra, Lindenberg i Veenstra, 2007) te pronalaze prijatelje sličnih osobina i ponašanja, od kojih dobivaju podršku za svoje nasilničko ponašanje (Pellegrini i sur., 1999). Jedan dio nasilne djece, posebice dječaka, zapravo su popularni, a njihova popularnost raste tijekom adolescencije (Parkhurst i Hopmeyer, 1998; Mouttapa i sur., 2004). Agresivne djevojčice manje su popularne, jer se njihova agresija ne smatra normativnim ponašanjem (Farmer i sur., 2002). Premda su istraživanja pokazala kako su nasilna djeca prihvaćena i mogu biti popularna unutar vršnjačkih grupa, to ne znači da su omiljena. Tjelesno nasilni dječaci, a posebice djevojčice, nisu omiljeni u društvu (Cillessen i Mayeux, 2004; LaFontana i Cillessen, 2002).

Istraživanja su pokazala kako je školska klima snažan prediktor uključenosti djece u nasilje i viktimizaciju (Barboza i sur., 2009; Kasen, Berenson, Cohen i Johnson, 2004). Negativni emocionalni odnos djeteta s nastavnikom povećava vjerojatnost javljanja nasilnoga ponašanja, posebice kod djece mlađe školske dobi (Hanish, Kochenderfer-Ladd, Fabes, Martin i Denning, 2004). Istraživanja pokazuju da nasilnici, ali i žrtve, imaju negativnu percepciju škole (Kasen i sur., 2004), dok žrtve školsko okruženje doživljavaju neprijateljskim i zastrašujućim (Aluede, Adeleke, Omoike i Afen-Akpaida, 2008; Harel-Fisch i sur., 2011). 
DRUŠ. ISTRAŽ. ZAGREB GOD. 22 (2013), BR. 1, STR. $101-120$

VELKI, T., VRDOLJAK, G.: ULOGA NEKIH...
Iz navedenoga pregleda istraživanja možemo zaključiti kako su se vršnjački odnosi i školsko okruženje pokazali značajnima za predviđanje vršnjačkoga nasilja i viktimizacije. Ipak, nisu svi rezultati prijašnjih istraživanja konzistentni. Uz to, većina opisanih istraživanja bavila se samo ukupnim vršnjačkim nasiljem, a nije jasno razdvojila različite vrste vršnjačkoga nasilja, pa nije u svojoj operacionalizaciji konstrukta vršnjačkoga nasilja uključila i elektroničko vršnjačko nasilje. Osim toga, većina istraživanja u svojoj metodologiji nije jasno razgraničila radi li se o vršnjakom zlostavljanju ili nasilju. Stoga je potrebno dodatno istraživanje koje će uzeti u obzir navedene nedostatke opisanih istraživanja, i to na uzorku hrvatske djece osnovnoškolske dobi, kao djece koja pohađaju specifični obrazovni sustav, koji se razlikuje od prijašnjih istraživanja provedenim uglavnom na američkom uzorku djece.

\section{CILJ ISTRAŽIVANJA}

Cilj ovog istraživanja jest ispitati potencijalne vršnjačke i školske prediktore vršnjačkoga nasilnog ponašanja na hrvatskom uzorku djece osnovnoškolske dobi. U ovom istraživanju mjereno je vršnjačko nasilje, a ne vršnjačko zlostavljanje (jer nije u obzir uzet nerazmjer u moći i namjera počinjenoga nasilnog ponašanja), pa su u skladu s tim prikazani rezultati i rasprava. Uz kontrolu spola, dobi i školskog uspjeha, cilj nam je provjeriti koji od odabranih vršnjačkih prediktora (broj prijatelja, socijalni status, prihvaćenost vršnjaka) i školskih prediktora (školska klima i sigurnost u školskom okruženju) predviđaju ukupno, verbalno i tjelesno vršnjačko nasilje te ukupnu, verbalnu i tjelesnu viktimizaciju.

\section{METODA}

\section{Sudionici}

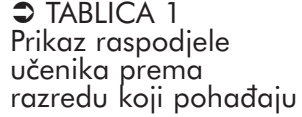

Sudjelovala su 262 učenika (43,1\% dječaka, 56,1\% djevojčica i dva učenika koja se nisu izjasnila o spolu) od petog do osmog razreda iz dvije osnovne škole u Slavoniji. Iz Osijeka je sudjelovalo 104 učenika, a iz Županje 158 učenika. Prosječna dob učenika bila je $\mathrm{M}=12,32(\mathrm{SD}=1,22)$, a raspon godina kretao se od 10 do 15 godina. U Tablici 1 prikazana je podjela učenika prema razredu što ga učenici pohađaju.

\begin{tabular}{lcc}
\hline Razred & Frekvencija & $\%$ \\
\hline 5. razred & 76 & 29,0 \\
6. razred & 54 & 20,6 \\
7. razred & 83 & 31,7 \\
8. razred & 49 & 18,7 \\
Ukupno & 262 & 100 \\
\hline
\end{tabular}




\section{Instrumenti}

\section{Upitnik o nasilju među školskom djecom}

(UNŠD; Velki, Kuterovac Jagodić i Vrdoljak, 2011)

Upitnik o nasilju među školskom djecom obuhvaća neke demografske karakteristike djeteta (dob, spol, razred, ocjene, broj prijatelja), zatim dva pitanja vezana uz osjećaj vršnjačke prihvaćenosti te pet pitanja vezanih uz osjećaj sigurnosti u školskom okruženju. Detaljnije je obuhvaćena učestalost počinjenoga i doživljenoga nasilja prema drugoj djeci. Skala nasilja među djecom i Skala viktimizacije sastoje se svaka od 19 čestica. Obje skale mogu se podijeliti na tri podskale koje mjere verbalno nasilje ( $\mathrm{k}=6$; npr. Govorim ružne riječi drugoj djeci), odnosno verbalnu viktimizaciju $(\mathrm{k}=6$; npr. Netko je govorio drugima ružno o tebi - ogovarao te), tjelesno nasilje ( $\mathrm{k}=7$; npr. Udarim ili gurnem nekog), odnosno tjelesnu viktimizaciju $(\mathrm{k}=7$; npr. Netko te jako istukao) i elektroničko nasilje $(k=6$; npr. Vrijeđam druge preko društvenih mreža), odnosno elektroničku viktimizaciju (k=6; npr. Netko ti je slao prijeteće ili uvredljive poruke ili pozive mobitelom). Sudionici istraživanja trebaju označiti učestalost doživljenoga/počinjenoga pojedinog oblika nasilja. Učestalost doživljenoga/počinjenoga nasilja bodovala se ovako: "nikad" nosi 1 bod, "rijetko (nekoliko puta u godini)" 2 boda, "ponekad (jednom na mjesec)" 3 boda, "često (nekoliko puta na mjesec)" 4 boda te "uvijek (skoro svaki dan)" 5 bodova. Rezultat se za svaku podskalu formira na temelju aritmetičkih sredina određenih čestica te se teoretski kreće u rasponu od 1 do 5 . Veći rezultat upućuje na veću učestalost doživljenog/počinjenog nasilja. Povezanost podskala istovjetnih vrsta nasilja i viktimizacije kreće se od 0,511 (za verbalno nasilje) do 0,616 (za ukupno nasilje). Koeficijenti pouzdanosti za podskale nasilničkoga ponašanja Cronbach $\alpha$ kretali su se od 0,66 do 0,83 , a za podskale viktimizacije od 0,70 do 0,87 . Prosječna korelacija među česticama za Skalu nasilja među djecom iznosi 0,392, dok za Skalu viktimizacije iznosi 0,324.

\section{Upitnik školske klime}

(UŠK - verzija za učenike; Velki, Kuterovac Jagodić i Antunović, 2011)

Upitnik školske klime odnosi se na osjećaj sigurnosti i pripadnosti školi (npr. Osjećam da pripadam školi koju pohađam), odnos nastavnika i učenika (npr. Učenici u mojoj školi imaju povjerenja u nastavnike), atmosferu učenja (npr. Buka u školi ometa me u učenju) te roditeljsku uključenost u školu (npr. Moji roditelji/skrbnici često dolaze u školu interesirati se za mene). Sastoji se od 15 tvrdnji. Namijenjen je učenicima od petog do osmog razreda osnovne škole. Dijete treba na skali Likertova tipa sa pet stupnjeva označiti slaganje s opisanim tvrdnjama. Pri tome 1 zna- 
DRUŠ. ISTRAŽ. ZAGREB GOD. 22 (2013), BR. 1, STR. $101-120$

VELKI, T., VRDOLJAK, G.: ULOGA NEKIH... či "potpuno se slažem", a 5 "uopće se ne slažem". Ukupni rezultat dobiva se na temelju aritmetičke sredine svih čestica i teoretski se kreće od 1 do 5 . Veći rezultat upućuje na negativniju školsku klimu. Koeficijent pouzdanost UŠK-a u našem istraživanju iznosi Cronbach $\alpha=0,92$. Prosječna korelacija među česticama iznosi 0,418.

\section{Sociometrijski postupak}

Svi sudionici dobili su popis učenika svojega razreda. Zadatak je bio da sudionik uz svako ime učenika stavi znak "+" ako mu se učenik sviđa kao prijatelj, odnosno znak "-" ako mu se učenik ne sviđa kao prijatelj, te preskočiti imena učenika prema kojima su neutralni. Za mjeru omiljenosti vršnjaka uzeli smo socijalni status koji smo izračunali tako da smo razliku sviđanja i nesviđanja za svaki razred podijelili s brojem učenika koji su sudjelovali u istraživanju.

\section{Postupak}

Svim učenicima omogućena je dragovoljnost i povjerljivost sudjelovanja u istraživanju. Prethodno su razrednici prikupili pismenu suglasnost roditelja za sudjelovanje $u$ istraživanju. Kako je istraživanje bilo dio školskih mjera protiv vršnjačkoga nasilja, svi su roditelji dali suglasnost, a samo djeca koja su bila bolesna ili iz nekih drugih razloga nisu bila u školi na dan kad se provodilo istraživanje nisu sudjelovala.

Podaci su prikupljeni grupno, za vrijeme nastave, $\mathrm{u}$ trajanju od oko 45 minuta. Pošto su im uputa i upitnici bili podijeljeni, školska psihologinja je uputila učenike u rješavanje sociometrijskoga postupka. Zatim su nastavili ispunjavati Upitnik o nasilju među školskom djecom te Upitnik školske klime. Vrijeme ispunjavanja upitnika nije bilo ograničeno. Svi su učenici uspjeli dati tražene podatke u okviru jednoga školskog sata. Nakon završetka ispunjavanja upitnika učenici su mogli postavljati pitanja te su dobili kontaktnu e-adresu ako naknadno budu imali dodatnih pitanja.

\section{REZULTATI I RASPRAVA}

Preduvjeti za provođenje parametrijske statistike i regresijske analize bili su zadovoljeni (prediktorske i kriterijske varijable su kvantitativne i na intervalnoj razini, varijance prediktora nisu nulte, ne postoji savršena multikolinearnost, prediktori nisu povezani s "vanjskim varijablama", zadovoljena je i homogenost varijance, Watson-Durbinov test je pokazao nezavisnost pogreške, distribucija pogreške ne razlikuje se statistički značajno od normalne distribucije, povezanost varijabli je linearna te su one nezavisno mjerene), stoga smo odlučili po- 


\section{Deskriptivna statistika}

Pri obradbi rezultata prvo smo izračunali deskriptivne statistike za varijable uključene $u$ istraživanje (Tablica 2). Za varijablu školski uspjeh koristili smo se prosječnom vrijednošću sume općeg uspjeha, uspjeha iz matematike i iz hrvatskoga jezika iz prethodnog razred te iz prethodnoga polugodišta. U osnovnoj školi učenici imaju uglavnom vrlo dobre i odlične ocjene, zbog čega je i smanjen varijabilitet u kriteriju opći uspjeh. Ocjene iz hrvatskoga jezika i matematike obično se smatraju glavnim predmetima u osnovnoj školi, pa su i kriteriji ocjenjivanja stroži. Valja očekivati da $\mathrm{u}$ tim varijablama varijabilitet bude veći u odnosu na opći uspjeh. Sociometrijskim

(1) TABLICA 2

Prikaz deskriptivne statistike za mjerene varijable postupkom izračunali smo socijalni status svakog učenika. Ostale varijable predstavljaju aritmetičku sredinu odgovarajućih skala i podskala UNŠD-a i UŠK-a.

\begin{tabular}{lrrrrr}
\hline & N & Minimum & Maksimum & M & SD \\
\hline Školski uspjeh & 261 & 1,33 & 5,00 & 3,90 & 0,878 \\
Broj prijatelja & 262 & 0 & 30 & 7,93 & 15,33 \\
Prihvaćenost vršnjaka & 262 & 1,00 & 3,00 & 2,61 & 0,457 \\
Socijalni status & 262 & $-0,74$ & 1,00 & 0,42 & 0,293 \\
Školska klima & 259 & 1,00 & 4,40 & 2,13 & 0,709 \\
Sigurnost u školskom okruženju & 262 & 1,00 & 3,00 & 2,58 & 0,383 \\
Ukupno vršnjačko nasilje & 262 & 1,00 & 3,47 & 1,32 & 0,325 \\
Verbalno vršnjačko nasilje & 262 & 1,00 & 4,00 & 1,62 & 0,534 \\
Tjelesno vršnjačko nasilje & 262 & 1,00 & 3,43 & 1,28 & 0,386 \\
Elektroničko vršnjačko nasilje & 262 & 1,00 & 3,00 & 1,08 & 0,214 \\
Ukupna vršnjačka viktimizacija & 262 & 1,00 & 4,16 & 1,63 & 0,501 \\
Verbalna vršnjačka viktimizacija & 262 & 1,00 & 4,83 & 2,07 & 0,794 \\
Tjelesna vršnjačka viktimizacija & 262 & 1,00 & 4,29 & 1,61 & 0,542 \\
Elektronička vršnjačka viktimizacija & 262 & 1,00 & 3,83 & 1,20 & 0,407 \\
\hline
\end{tabular}

Rezultati deskriptivne statistike u skladu su s očekivanjima. Iako nemamo puni raspon za sve varijable, kako se radi o mjerenju nasilnoga ponašanja i viktimizacije, nismo ni očekivali da će učenici na određenim podskalama iskazivati/doživljavati sve oblike nasilnoga ponašanja.

\section{Usporedba prevalencija vršnjačkoga nasilja u Hrvatskoj}

Prijašnja su istraživanja u kategorizaciji učenika najčešće rabila dva "granična" kriterija, pri čemu je blaži kriterij definiran učestalošću nasilničkoga ponašanja koje se događa jednom na mjesec, dok je stroži kriterij definiran učestalošću nasilničkoga ponašanja koje se događa više puta na mjesec ili češće (Cook i sur., 2010). U skladu s tim, uzeli smo stroži kriterij te smo učenika identificirali kao počinitelja nasilja ako je barem na jednoj čestici odgovarajuće podskale označio da opisano 
DRUŠ. ISTRAŽ. ZAGREB GOD. 22 (2013), BR. 1, STR. $101-120$

VELKI, T., VRDOLJAK, G.: ULOGA NEKIH...

\footnotetext{
- TABLICA 3

Prikaz prevalenciie vršnjačkoga nasilja
}

puta na mjesec)", a kao žrtvu ako je barem na jednoj čestici odgovarajuće podskale označio da mu se opisano ponašanje događa "uvijek (skoro svaki dan)" ili "često (nekoliko puta na mjesec)". Učenika smo identificirali kao provokativnu žrtvu ako je označio da istodobno opisano ponašanje čini "uvijek" ili "često" te ako mu se opisano ponašanje događa "uvijek" ili "često" (Tablica 3).

\begin{tabular}{lcrc}
\hline & $\begin{array}{c}\text { Počinitelji } \\
\text { nasilja }\end{array}$ & Žrtve & $\begin{array}{c}\text { Provokativne } \\
\text { žrtve }\end{array}$ \\
\hline Ukupno vršnjačko nasilje & $3,1 \%$ & $30,9 \%$ & $13,7 \%$ \\
Verbalno vršnjačko nasilje & $3,1 \%$ & $26,7 \%$ & $8,0 \%$ \\
Tjelesno vršnjačko nasilje & $2,7 \%$ & $24,0 \%$ & $7,3 \%$ \\
Elektroničko vršnjačko nasilje & $0,8 \%$ & $6,5 \%$ & $1,1 \%$ \\
\hline
\end{tabular}

Naši rezultati vrlo su slični rezultatima dobivenim na nacionalnom uzorku (2,3\% počinitelja nasilja, 14,4\% žrtava i 7,7\% provokativnih žrtvi; Sušac i sur., 2012) i uzorku osječke djece (4\% počinitelja nasilja, 30\% žrtava i $14 \%$ provokativnih žrtava; Velki, 2012a). Kako su u uzorku bila djeca iz dva slavonska grada, naši rezultati, iako nisu dobiveni na reprezentativnom uzorku, omogućuju pouzdano zaključivanje o problematici vršnjačkoga nasilja. Naime, dobiveni rezultati pokazuju vrlo sličnu prevalenciju koja je dobivena na nacionalnom uzorku djece iste dobi te gotovo istu prevalenciju ukupnoga vršnjačkog nasilja dobivenu na uzorku osječke djece, što upućuje na to da smo dobro zahvatili populaciju s obzirom na problematiku vršnjačkoga nasilja.

Zbog maloga broja počinitelja i žrtava elektroničkoga nasilja, to vršnjačko nasilje nije uzeto kao zasebna kriterijska varijabla u daljnjoj analizi. Ovaj je rezultat očekivan i u skladu je s prijašnjim istraživanjima (Williams i Guerra, 2007; Smith i Slonje, 2010), koja govore o prevalenciji počinjenog elektroničkog nasilja od 4,5\% (peti razred osnovne škole) do 12,9\% (osmi razred osnovne škole) u SAD-u te o prevalenciji žrtava od 3,6\% (Japan), 4,8\% (Južna Koreja), 6,9\% (Australija) do čak 13\% (Kanada). Velike razlike u učestalosti elektroničkoga nasilja odraz su definiranja i mjerenja ovoga konstrukta, pri čemu se često miješa samo elektroničko nasilje s ostalim neprimjerenim sadržajima na internetu. Ako ta dva konstrukta nisu jasno razlučena, rezultati istraživanja pokazuju veliku prevalenciju elektroničkoga nasilja, a kako smo svoje istraživanje ograničili samo na elektroničko nasilje, pri čemu nismo pitali o drugim neprimjerenim sadržajima s kojima učenici dolaze $u$ doticaj na internetu, dobivena mala prevalencija elektroničkoga nasilja bila je očekivana. Ipak, elektroničko vršnjačko nasilje dio je konstrukta ukupnoga vršnjačkog nasilja i kao takvo uključeno je $\mathrm{u}$ daljnje analize. 


\section{Predviđanje vršnjačkoga nasilja i viktimizacije}

Podatke smo analizirali hijerarhijskom regresijskom analizom, kako bismo utvrdili značajnost prediktora za ukupno, verbalno i tjelesno vršnjačko nasilje. Ukupno je provedeno šest hijerarhijskih regresijskih analiza - tri za počinitelje nasilja (Tablica 4) i tri za žrtve nasilja (Tablica 5). Prediktori koje smo uključili u analizu u prvom koraku hijerarhijske regresijske analize jesu: spol i dob učenika te prosjek ocjena, u drugom koraku dodali smo vršnjačke varijable: broj najboljih prijatelja, socijalni status i prihvaćenost vršnjaka, dok smo u trećem koraku do-

(1) TABLICA 4

Regresijska analiza za počinitelje vršnjačkoga nasilja

\begin{tabular}{|c|c|c|c|}
\hline $\begin{array}{l}\text { Kriteriji/ } \\
\text { Prediktori }\end{array}$ & $\begin{array}{l}\text { Ukupno } \\
\text { vršnjačko nasilje } \\
\beta\end{array}$ & $\begin{array}{l}\text { Verbalno } \\
\text { vršnjačko nasilje } \\
\beta\end{array}$ & $\begin{array}{l}\text { Tjelesno } \\
\text { vršnjačko nasilje } \\
\beta\end{array}$ \\
\hline Spol & $-0,207^{* *}$ & $-0,096$ & $-0,335^{* *}$ \\
\hline Dob & $0,266^{* *}$ & $0,285^{* *}$ & $0,239 * *$ \\
\hline Školski uspjeh & $-0,070$ & $-0,078$ & $-0,039$ \\
\hline Regresijski model & $\begin{array}{l}\mathrm{R}=0,367 ; \mathrm{R}^{2}=0,135 \\
\mathrm{R}^{2} \text { kor }=0,125 \\
\mathrm{~F}(3,255)=13,090 ; \mathrm{p}<0,001\end{array}$ & $\begin{array}{l}\mathrm{R}=0,332 ; \mathrm{R}^{2}=0,110 \\
\mathrm{R}^{2} \text { kor }=0,100 \\
\mathrm{~F}(3,255)=10,419 ; \mathrm{p}<0,001\end{array}$ & $\begin{array}{l}\mathrm{R}=0,429 ; \mathrm{R}^{2}=0,184 \\
\mathrm{R}^{2} \text { kor }=0,174 \\
\mathrm{~F}(3,255)=18,894 ; \mathrm{p}<0,001\end{array}$ \\
\hline Spol & $-0,163^{* *}$ & $-0,070$ & $-0,293^{* *}$ \\
\hline Dob & $0,332^{* *}$ & $0,333^{* *}$ & $0,301^{* *}$ \\
\hline Školski uspjeh & $-0,018$ & $-0,031$ & 0,009 \\
\hline Broj prijatelja & $0,246^{* *}$ & $0,147^{*}$ & $0,225^{* *}$ \\
\hline Socijalni status & $-0,137^{*}$ & $-0,102$ & $-0,135^{*}$ \\
\hline Prihvaćenost vršnjaka & $-0,097$ & 0,115 & $-0,075$ \\
\hline Regresijski model & $\begin{array}{l}\mathrm{R}=0,487 ; \mathrm{R}^{2}=0,237 \\
\mathrm{R}^{2} \text { kor }=0,218 \\
\mathrm{~F}(6,255)=12,872 ; \mathrm{p}<0,001\end{array}$ & $\begin{array}{l}R=0,404 ; R^{2}=0,163 \\
R^{2} \text { kor }=0,143 \\
F(3,255)=8,108 ; p<0,001\end{array}$ & $\begin{array}{l}R=0,519 ; R^{2}=0,269 \\
R^{2} \text { kor }=0,252 \\
F(3,255)=15,295 ; p<0,001\end{array}$ \\
\hline Spol & $-0,133^{*}$ & $-0,046$ & $-0,259^{* *}$ \\
\hline Dob & $0,206^{* *}$ & $0,225^{* *}$ & $0,164^{*}$ \\
\hline Školski uspjeh & 0,008 & $-0,010$ & 0,040 \\
\hline Broj prijatelja & $0,260^{*}$ & $0,161^{* *}$ & $0,238^{* *}$ \\
\hline Socijalni status & $-0,128^{*}$ & $-0,092$ & $-0,129^{*}$ \\
\hline Prihvaćenost vršnjaka & $-0,021$ & $-0,036$ & $-0,004$ \\
\hline $\begin{array}{l}\text { Školska klima } \\
\text { Sigurnost u }\end{array}$ & $0,278^{* *}$ & $0,237^{* *}$ & $0,303^{* *}$ \\
\hline školskom okruženju & $-0,063$ & $-0,089$ & $-0,037$ \\
\hline Regresijski model & $\begin{array}{l}\mathrm{R}=0,550 ; \mathrm{R}^{2}=0,303 \\
\mathrm{R}^{2} \text { kor }=0,280 \\
\mathrm{~F}(8,255)=13,401 ; \mathrm{p}<0,001\end{array}$ & $\begin{array}{l}R=0,468 ; R^{2}=0,219 \\
R^{2} \text { kor }=0,194 \\
F(3,255)=8,680 ; p<0,001\end{array}$ & $\begin{array}{l}R=0,583 ; R^{2}=0,340 \\
R^{2} \text { kor }=0,319 \\
F(3,255)=15,918 ; p<0,001\end{array}$ \\
\hline
\end{tabular}
tri kriterija (ukupno, tjelesno i verbalno vršnjačko nasilno ponašanje) i obje kriterijske skupine djece (žrtve i počinitelji nasilja) služili smo se istim prediktorima. 
DRUŠ. ISTRAŽ. ZAGREB GOD. 22 (2013), BR. 1, STR. $101-120$

VELKI, T., VRDOLJAK, G.: ULOGA NEKIH...
U skladu s očekivanjima (Barboza i sur., 2009; Pellegrini i sur., 1999), i vršnjačke i školske varijable pokazale su se značajnima za predviđanje vršnjačkoga nasilja (Tablica 4), uz kontrolu individualnih karakteristika. Odabrani prediktori najbolje objašnjavaju tjelesno vršnjačko nasilje (31,9\%), zatim ukupno vršnjačko nasilje (28\%), a najslabije verbalno vršnjačko nasilje $(19,4 \%)$.

\begin{tabular}{|c|c|c|c|}
\hline $\begin{array}{l}\text { Kriteriji/ } \\
\text { Prediktori }\end{array}$ & $\begin{array}{l}\text { Ukupna vršnjačka } \\
\text { viktimizacija } \\
\beta\end{array}$ & $\begin{array}{l}\text { Verbalna vršnjačka } \\
\text { viktimizacija } \\
\beta\end{array}$ & $\begin{array}{l}\text { Tjelesna vršnjačka } \\
\text { viktimizacija } \\
\beta\end{array}$ \\
\hline Spol & $-0,092$ & $-0,109$ & $-0,139^{*}$ \\
\hline Dob & 0,110 & $0,138^{*}$ & 0,121 \\
\hline Školski uspjeh & $-0,097$ & $-0,073$ & $-0,070$ \\
\hline \multirow[t]{3}{*}{ Regresijski model } & $\mathrm{R}=0,197 ; \mathrm{R}^{2}=0,039$ & $\mathrm{R}=0,210 ; \mathrm{R}^{2}=0,044$ & $\mathrm{R}=0,217 ; \mathrm{R}^{2}=0,047$ \\
\hline & $\mathrm{R}^{2}$ kor $=0,027$ & $\mathrm{R}^{2}$ kor $=0,033$ & $\mathrm{R}^{2}$ kor $=0,036$ \\
\hline & $\mathrm{F}(3,255)=3,383 ; \mathrm{p}<0,019$ & $\mathrm{~F}(3,255)=3,893 ; \mathrm{p}<0,010$ & $\mathrm{~F}(3,255)=4,150 ; \mathrm{p}<0,007$ \\
\hline Spol & $-0,070$ & $-0,100$ & $-0,115$ \\
\hline Dob & $0,193^{* *}$ & $0,213^{*}$ & $0,189^{* *}$ \\
\hline Školski uspjeh & 0,019 & 0,050 & 0,017 \\
\hline Broj prijatelja & $0,115^{*}$ & 0,051 & $0,129^{*}$ \\
\hline Socijalni status & $-0,205^{* *}$ & $-0,187^{* *}$ & $-0,165^{*}$ \\
\hline Prihvaćenost vršnjaka & $-0,364^{* *}$ & $-0,430^{* *}$ & $-0,257^{* *}$ \\
\hline \multirow[t]{3}{*}{ Regresijski model } & $\mathrm{R}=0,505 ; \mathrm{R}^{2}=0,255$ & $\mathrm{R}=0,540 ; \mathrm{R}^{2}=0,292$ & $\mathrm{R}=0,419 ; \mathrm{R}^{2}=0,175$ \\
\hline & $\mathrm{R}^{2}$ kor $=0,237$ & $\mathrm{R}^{2}$ kor $=0,275$ & $\mathrm{R}^{2}$ kor $=0,155$ \\
\hline & $\mathrm{F}(6,255)=4,210 ; \mathrm{p}<0,001$ & $\mathrm{~F}(3,255)=7,119 ; \mathrm{p}<0,001$ & $\mathrm{~F}(3,255)=8,822 ; \mathrm{p}<0,001$ \\
\hline Spol & $-0,041$ & $-0,073$ & $-0,090$ \\
\hline Dob & 0,074 & 0,096 & 0,074 \\
\hline Školski uspjeh & 0,044 & 0,074 & 0,039 \\
\hline Broj prijatelja & $0,127^{*}$ & 0,065 & $0,144^{*}$ \\
\hline Socijalni status & $-0,198^{* *}$ & $-0,178^{* *}$ & $-0,153^{*}$ \\
\hline Prihvaćenost vršnjaka & $-0,296^{* *}$ & $-0,354^{* *}$ & $-0,167^{* *}$ \\
\hline Školska klima & $0,263^{* *}$ & $0,258^{* *}$ & $0,252^{* *}$ \\
\hline \multicolumn{4}{|l|}{ Sigurnost $\mathrm{u}$} \\
\hline školskom okruženju & $-0,050$ & $-0,069$ & $-0,109$ \\
\hline \multirow[t]{3}{*}{ Regresijski model } & $\mathrm{R}=0,558 ; \mathrm{R}^{2}=0,312$ & $\mathrm{R}=0,593 ; \mathrm{R}^{2}=0,351$ & $\mathrm{R}=0,492 ; \mathrm{R}^{2}=0,242$ \\
\hline & $\mathrm{R}^{2}$ kor $=0,289$ & $\mathrm{R}^{2} \mathrm{kor}=0,330$ & $\mathrm{R}^{2}$ kor $=0,218$ \\
\hline & $\mathrm{F}(8,255)=3,987 ; \mathrm{p}<0,001$ & $\mathrm{~F}(3,255)=6,705 ; \mathrm{p}<0,001$ & $\mathrm{~F}(3,255)=9,879 ; \mathrm{p}<0,001$ \\
\hline
\end{tabular}

${ }^{* *} \mathrm{p}<0,01 ;{ }^{*} \mathrm{p}<0,05$

(1) TABLICA 5 Regresijska analiza za žrtve vršnjačkoga nasilja
Za predviđanje ukupnoga i tjelesnoga vršnjačkog nasilja značajnima su se pokazali isti prediktori, i to spol, dob, broj najboljih prijatelja, socijalni status i školska klima (iako su isti prediktori objasnili nešto veći postotak varijance tjelesnoga vršnjačkog nasilja u odnosu na ukupno vršnjačko nasilje). Individualne varijable objašnjavaju velik dio varijance $(12,5 \%$ do 
DRUŠ. ISTRAŽ. ZAGREB GOD. 22 (2013), BR. 1 STR. 101-120

VELKI, T., VRDOLJAK, G.: ULOGA NEKIH...
17,4\% objašnjene varijance). Stariji dječaci iskazuju značajno više ukupnoga i tjelesnoga vršnjačkog nasilja, što je u skladu s očekivanjima. Tijekom osnovne škole dolazi do porasta agresije s dobi te najviše agresije iskazuju djeca u završnim razredima osnovne škole i nižim razredima srednje škole. Istraživanja pokazuju značajan porast nasilja između 11. i 15. godine, ulaskom u pubertet i prelaskom iz osnovne škole u srednju (Espelage, Mebane i Swearer, 2004). Ulaskom u adolescenciju djeca su sklonija pozitivnijim stavovima o iskazivanju nasilja, posebice dječaci, a nasilje im služi i kao mehanizam za stjecanje dominacije i popularnosti (Bukowski, Sippola i Newcomb, 2000; LaFontana i Cillessen, 2002; Parkhurst i Hopmeyer, 1998). Stoga ne čudi što s porastom dobi raste i nasilno ponašanje. Od vršnjačkih varijabli značajne su bile broj prijatelja, pri čemu nasilnija djeca imaju veći broj prijatelja, te socijalni status, pri čemu nasilnija djeca imaju negativan socijalni status, odnosno iako su popularna, nisu omiljena u društvu vršnjaka. Istraživanja su pokazala kako se djeca češće druže s vršnjacima slična ponašanja kako se ponašaju i ona sama (Haselager, Hartup, van Lieshout i Riksen-Walraven, 1998; Pellegrini i sur., 1999), pa u skladu s tim agresivna djeca imaju više prijatelja koji vole kršiti pravila (Bagwell i Coie, 2004; Dijkstra i sur., 2007). Nasilna djeca pronalaze prijatelje koji podržavaju njihovo nasilno ponašanje, što im služi kao dodatni poticaj i potkrepljenje za nasilničko ponašanje prema vršnjacima te takvim ponašanjem pokušavaju steći status i prihvaćanje u grupi sličnih vršnjaka. Ipak, to ne znači da su oni omiljeni u društvu. Istraživanja su pokazala kako tjelesno nasilni dječaci, a posebice djevojčice, nisu omiljeni u društvu (Cillessen i Mayeux, 2004; LaFontana i Cillessen, 2002). Nasilna djeca imaju velik broj "pseudoprijatelja", odnosno vršnjaka koji se boje da će i sami postati žrtvama njihova nasilničkog ponašanja ako se ne budu družila s njima. Iako se čini da imaju velik broj prijatelja, nasilna djeca imaju zapravo manji broj prijatelja, koji su sličnoga ponašanja kao i ona sama, dok ih ostala djeca prihvaćaju jer to smatraju mehanizmom obrane od njihova ponašanja, a ne zato što žele imati s njima prijateljske odnose (npr. ne vole se družiti ni igrati s njima). Od školskih varijabli značajnom za predviđanje ukupnoga i tjelesnoga vršnjačkog nasilja pokazala se negativna školska klima (koja sama dodatno objašnjava oko 6\% varijance), što je u skladu s prijašnjim istraživanjima (Barboza i sur., 2009; Kasen i sur., 2004). U školama gdje prevladava negativna školska klima učenici nemaju osjećaj pripadnosti školi, nisu emocionalno vezani uz školu, štoviše, škola im je samo neugodna obveza i skloni su je izbjegavati. U takvim školama nastavnici nisu uspješni u rješavanju problema vršnjačkoga nasilja. Najviše 
DRUŠ. ISTRAŽ. ZAGREB GOD. 22 (2013), BR. 1, STR. $101-120$

VELKI, T., VRDOLJAK, G.: ULOGA NEKIH... vršnjačkoga nasilja javlja se $u$ razredima gdje su nastavnici hladni prema učenicima, ne odgovaraju na djetetove potrebe te nemaju jednake kriterije za sve učenike unutar razreda (Newman, Murray i Lussier, 2001; Olweus i Limber, 1999). Takvo nezdravo ozračje samo je dodatni poticaj za vršnjačko nasilje, a ne da se potencira njegovo rješavanje.

Za razliku od ukupnoga i tjelesnoga vršnjačkog nasilja, verbalno smo vršnjačko nasilno ponašanje slabije uspjeli objasniti zadanim varijablama. Manji je i broj značajnih prediktora. Od individualnih varijabli značajnom se pokazala samo dob učenika, pri čemu s porastom dobi raste i nasilje, što je u skladu i s prijašnjim istraživanjima. Stariji učenici smatraju kako nastavnici ne provode dovoljno nadzora nad njima (posebice za vrijeme odmora), što tim učenicima daje više prilika za iskazivanje nasilničkoga ponašanja, za koja smatraju da mogu proći nekažnjeno (Velki, 2010). Ako i primijete sukobe, nastavnici će se rjeđe miješati u učeničke odnose i raspravu kada su u pitanju stariji učenici, osim u slučaju težega tjelesnog nasilja. Za razliku od ukupnoga i tjelesnoga vršnjačkog nasilja, spol se nije pokazao značajnim prediktorom verbalnoga vršnjačkog nasilja. Od vršnjačkih varijabli značajnom za predviđanje verbalnoga vršnjačkog nasilja pokazala se samo varijabla broj prijatelja, pri čemu verbalno nasilniji učenici imaju veći broj prijatelja, što je u skladu s postavkama o uspostavi dominacije i popularnosti adolescenata vršnjačkim nasiljem (Pellegirni i sur., 2010). Kao i kod ukupnoga i tjelesnoga vršnjačkog nasilja, negativna školska klima povezana je s porastom verbalnoga vršnjačkog nasilja, što je u skladu s očekivanjima.

Uz kontrolu individualnih varijabli, boljim prediktorima ukupnoga i tjelesnoga vršnjačkog nasilja pokazale su se vršnjačke varijable, dok su školske varijable bolje predviđale verbalno vršnjačko nasilje. Ovakvi su rezultati očekivani i u skladu s prijašnjim istraživanjima (Cillessen i Mayeux, 2004; LaFontana i Cillessen, 2002; Harel-Fisch i sur., 2011; Kasen i sur., 2004). Tjelesno vršnjačko nasilje jest oblik izravnog napada, koje vide i sami vršnjaci, pa se lakše postavlja granica između nasilja i šale. Stoga je očekivano da smo upravo tjelesno vršnjačko nasilje najbolje uspjeli predvidjeti zadanim varijablama, posebice vršnjačkim, jer su vršnjaci direktno uključeni i na "vlastitoj koži" osjete posljedice tjelesnoga nasilnog ponašanja. Verbalno vršnjačko nasilje često nije jasno vidljivo, a i nastavnici i vršnjaci slabije reagiraju kada dođe do verbalnoga sukoba. Upravo zato negativna školska klima, koja zahvaća odnose učenika i nastavnika te općenito klimu koja prevladava u školi i samom razredu, za razliku od vršnjačkih varijabli, bolje predviđa ovakav suptilniji oblik vršnjačkoga nasilja. 


\section{Vršnjačka viktimizacija}

U skladu s očekivanjima (Barboza i sur., 2009; Pellegrini i sur., 1999), i vršnjačke i školske varijable pokazale su se značajnima za predviđanje vršnjačke viktimizacije (Tablica 5), uz kontrolnu individualnih karakteristika. Odabrani prediktori najbolje objašnjavaju verbalnu viktimizaciju (33\%), zatim ukupnu viktimizaciju (28,9\%), a najslabije tjelesnu viktimizaciju $(21,8 \%)$.

Za predviđanje ukupne vršnjačke viktimizacije značajnima su se pokazale sve vršnjačke varijable, broj prijatelja, socijalni status, prihvaćenost vršnjaka (objašnjavaju $21 \%$ varijance) te školska klima (objašnjava oko $5 \%$ varijance). Dob, u smjeru da su stariji učenici češće žrtve nasilja, pokazao se značajnim prediktorom samo $\mathrm{u}$ jednom koraku, dok $\mathrm{u}$ konačnoj soluciji ni jedna individualna karakteristika nije značajno predviđala ukupnu vršnjačku viktimizaciju. Iako je možda ovo pomalo iznenađujući rezultat jer su prijašnja istraživanja u svijetu pokazala smanjenje broja žrtava s porastom dobi (Olweus, 1998), treba uzeti u obzir da smo u ovom istraživanju zahvatili samo učenike od 5. do 8. razreda osnovne škole. Naši su rezultati u skladu s istraživanjima u Hrvatskoj (Sušac i sur., 2012; Velki, 2012a), koja su pokazala da su učenici u završnim razredima osnovne škole više uključeni u nasilje, bilo kao žrtve ili nasilnici (14,4\% žrtava u 5. razredu i $17,6 \%$ u 7. razredu osnovne škole; Sušac i sur., 2012). Očekivane rezultate dobili smo za vršnjačke prediktore: socijalni status i prihvaćenost vršnjaka. Žrtve vršnjačkoga nasilja imaju negativan socijalni status, odnosno nisu omiljeni u društvu, pa su i slabije prihvaćeni. Istraživanja pokazuju da su provokativne žrtve najmanje omiljene, a odmah iza njih dolaze žrtve (Mynard i Joseph, 1997). Žrtve imaju najviše problema u odnosima s vršnjacima (Marini, Dane i Bosacki, 2006), nepopularne su i vršnjaci ih često odbacuju (Hodges, Boivin, Vitaro i Bukowski, 1999; Olweus, 1998). Žrtve vršnjačkoga nasilja teško uspostavljaju prijateljske odnose s vršnjacima, teško prilaze drugoj djeci, a ni vršnjaci ne žele s njima biti u društvu jer time povećavaju vjerojatnost da će i sami postati buduće žrtve vršnjačkoga nasilja. Iako ih jednim dijelom vršnjaci odbacuju iz straha da i sami ne postanu žrtve, drugim dijelom zbog povećane anksioznosti i nekih drugih karakteristika (Olweus, 1998) žrtve pokazuju neprilagođeno ponašanje u odnosima s vršnjacima i zato su slabije prihvaćene. U našem istraživanju veći broj prijatelja predviđa i veću viktimizaciju. Iako su ovi rezultati pomalo neočekivani, jer su prijašnja istraživanja pokazala da žrtve imaju manji broj prijatelja (Dake i sur., 2003; Mouttapa i sur., 2004), treba uzeti u obzir tko su prijatelji djece žrtava. Žrtve vršnjačkoga nasilja češće se druže međusobno, s djecom koja su i sama žrtve i izolirana su. Stoga, iako žrtve 
DRUŠ. ISTRAŽ. ZAGREB GOD. 22 (2013), BR. 1, STR. $101-120$

VELKI, T., VRDOLJAK, G.: ULOGA NEKIH... vršnjačkoga nasilja imaju zadovoljavajuću socijalnu mrežu, njihovi prijatelji nisu im od pomoći kada je u pitanju vršnjačko nasilje. Procjena broja prijatelja za djecu žrtve nije recipročna, odnosno iako ona navode da imaju puno prijatelja, njih druga djeca ne biraju i ne navode kao prijatelje tako često (Pellegrini i Long, 2002). Njihovi su prijatelji i sami najčešće žrtve, što povećava vjerojatnost dodatne viktimizacije, jer ih prijatelji ne mogu zaštititi od nasilja te postaju "lake mete" nasilnicima. Stoga je moguće da veći broj prijatelja za djecu žrtve zapravo znači njihovu pogrešnu procjenu (nisu recipročna prijateljstva) ili odabir prijatelja koji su i sami žrtve, što povećava vjerojatnost viktimizacije. Osim vršnjačkih varijabli, značajnim prediktorom pokazala se i školska klima (objašnjava 5,2\% varijance), pri čemu negativna školska klima predviđa i više ukupne viktimizacije. Dobiveni su rezultati u skladu s očekivanjima. Žrtve nasilništva, osim što školsku klimu smatraju negativnom, školsko okruženje doživljavaju neprijateljskim i zastrašujućim (Aluede i sur., 2008; Harel-Fisch i sur., 2011). Kako u školama u kojima prevladava negativna školska klima ima općenito više vršnjačkoga nasilja, učenici su češće izloženi svakodnevnom nasilju, pa je veća vjerojatnost da će i sami postati žrtve vršnjačkoga nasilja. Uz to, u ovim školama nastavnici ne uspostavljaju bliske odnose $\mathrm{s}$ učenicima, pa se žrtve nemaju komu povjeriti i obratiti za pomoć, a ako to i učine, nazivaju ih "tužibabama".

Isti značajni prediktori dobiveni su i za tjelesnu vršnjačku viktimizaciju, iako mnogo slabije $(21,8 \%$ objašnjene varijance) predviđaju tjelesnu viktimizaciju. Jedina razlika između ukupne i tjelesne vršnjačke viktimizacije javila se u prvom koraku regresijske analize, pri čemu se muški spol pokazao značajnim prediktorom tjelesne viktimizacije (iako u ostalim koracima i završnoj soluciji nije više bio značajan). Kako su dječaci češće uključeni u nasilno ponašanje (bilo kao žrtve ili nasilnici), posebice kada je u pitanju tjelesno vršnjačko nasilje koje se smatra djelomično normativnim ponašanjem dječaka, odnosno dijelom njihova odrastanja (Espelage i sur., 2000; McDermott, 1996; Olweus, 2010) dobiveni su rezultati očekivani.

Najviše razlika pojavilo se u predviđanju verbalne vršnjačke viktimizacije. Isto kao i kod ukupne i tjelesne vršnjačke viktimizacije, dob kao značajan prediktor (starija su djeca više verbalno viktimizirana) pojavio se u prvom i drugom koraku regresijske analize, dok u završnoj soluciji više nije bio značajan prediktor. Za razliku od ukupne i tjelesne vršnjačke viktimizacije, kod verbalne viktimizacije broj prijatelja nije bio značajan prediktor, dok su se ostali vršnjački (negativan socijalni status i slaba prihvaćenost vršnjaka) i školski prediktori (negativna školska klima) pokazali značajnima za predviđanje 
DRUŠ. ISTRAŽ. ZAGREB GOD. 22 (2013), BR. 1 STR. 101-120

VELKI, T., VRDOLJAK, G.: ULOGA NEKIH... verbalne vršnjačke viktimizacije u očekivanom smjeru. Iako smo u završnoj soluciji verbalne viktimizacije imali jedan značajan prediktor manje (za razliku od ukupne i tjelesne viktimizacije), verbalnu viktimizaciju uspjeli smo najbolje objasniti zadanim prediktorima ( $33 \%$ objašnjene varijance).

Uz kontrolu individualnih varijabli, boljim prediktorima svih triju vršnjačkih viktimizacija pokazale su se vršnjačke varijable, što je u skladu s očekivanjima. Vršnjaci su ti koji određuju grupnu dinamiku, i upravo o njihovim reakcijama i načinu odnošenja prema drugoj djeci (npr. hoće li stati u obranu žrtava vršnjačkoga nasilja ili će poticati nasilje) ovisi i razvoj vršnjačkoga nasilja.

U provedenom istraživanju dva potencijalna prediktora nisu se pokazala značajnima ni za predviđanje nasilnog ponašanja ni za viktimizaciju. Iako smo pretpostavili da će slabiji školski uspjeh biti značajan prediktor nasilnoga ponašanja i viktimizacije (Dake i sur., 2003; Farrington, 1997; Nansel i sur., 2001; Profaca i sur., 2006), ova varijabla nije se pokazala značajnom. Jedan dio popularne nasilne djece ima dobro razvijene kognitivne sposobnosti, koje im osiguravaju odličan školski uspjeh, ali ih istodobno rabe i u manipulaciji drugima (posebice kod relacijskoga vršnjačkog nasilja), pa često nisu ni od nastavnika prepoznati kao počinitelji nasilja niti su kažnjeni u skladu sa svojim ponašanjem. Jedan dio žrtava vršnjačkoga nasilja zapravo su odlični učenici koji su često i miljenici nastavnika, a time i potencijalne žrtve nasilne djece, dok drugi dio djece žrtava zbog stalne izloženosti vršnjačkom nasilju i niza poteškoća vezanih uz viktimizaciju ima i slabiji školski uspjeh. Ni varijabla sigurnost u školskom okruženju nije se pokazala značajnom ni za predviđanje vršnjačkoga nasilja ni viktimizacije. Moguće je da smo prediktorom školske klime (npr. česticom $U$ školi se osjećam sigurno) zahvatili i aspekte osjećaja sigurnosti u školi, tako da ova varijabla nije imala značajnoga doprinosa. Školska klima obuhvaća različite aspekte (npr. osjećaj pripadnosti školi, odnos učenika i nastavnika, osjećaj sigurnosti), dok je osjećaj sigurnosti samo jedan dio konstrukta školske klime, koji smo detaljnije ispitali u sklopu Upitnika o nasilju među školskom djecom.

Gledajući cjelokupnu sliku, možemo zaključiti kako su se slični vršnjački i isti školski prediktori pokazali značajnima za predviđanje vršnjačkoga nasilja i viktimizacije. Vršnjačke varijable bolje objašnjavaju viktimizaciju, jer su one odraz dinamike grupe koja je uvjetovana i određenim situacijskim činiteljima, a upravo je viktimizacija češće vezana uz situacijske činitelje (npr. tko je sve prisutan na hodniku), za razliku od nasilnoga ponašanja, koje je više određeno individualnim i obiteljskim faktorima (Velki, 2012a). Individualne varijable bolje objašnjavaju predviđanje nasilnoga ponašanja. Nasilno je po- 
DRUŠ. ISTRAŽ. ZAGREB GOD. 22 (2013), BR. 1, STR. $101-120$

VELKI, T., VRDOLJAK, G.: ULOGA NEKIH... našanje djelomično i biološki uvjetovano, a okolina je ta koja potiče njegovo kazivanje (Moffit, 2005), stoga ne čudi što su upravo individualne karakteristike bolje u predviđanju vršnjačkoga nasilja. Osim toga, školska je klima dobar pokazatelj cijeloga konteksta u kojem se odvija dječje nasilno ponašanje, pa kao takva može u oba slučaja (i nasilja i viktimizacije) poslužiti kao facilitator (negativna školska klima) ili inhibitor (pozitivna školska klima) dječjega nepoželjnog ponašanja.

Iako su rezultati ovoga istraživanja očekivani i u skladu s prijašnjim istraživanjima u svijetu, treba napomenuti i nekoliko nedostataka. Prvo, uzorak nije bio reprezentativan, što nam smanjuje mogućnost generalizacije. Ipak, usporedbom s prijašnjim istraživanjima na nacionalnom i osječkom uzorku djece (Sušac i sur., 2012; Velki, 2012a) možemo zaključiti da dobro predstavlja populaciju slavonske djece s obzirom na problematiku vršnjačkoga nasilja. Drugo, istraživanje nije bilo anonimno. Moguće je da su djeca zbog toga davala socijalno poželjne odgovore, odnosno da nisu potpuno iskreno odgovarala na pitanja iz upitnika. Treće, nisu sva djeca koja su sudjelovala $u$ istraživanju pristala da njihove podatke vezane uz sociometrijski postupak rabimo, što je moglo utjecati na reprezentativnost uzorka. Učenici koji nisu pristali da rabimo njihove sociometrijske podatke procjenjuju kako provode više verbalnoga nasilnog ponašanja prema vršnjacima, $F(1,261)=5,17$, $p<0,05$. Četvrto, pri određenju kriterija nasilnoga ponašanja i viktimizacije služili smo se samo metodom samoprocjene. Moguće je da učenici nisu dovoljno objektivni u samoprocjeni, odnosno da precjenjuju ili podcjenjuju količinu doživljenoga i počinjenoga nasilnog ponašanja. I na kraju, mnoga istraživanja pokazuju da postoji niz drugih potencijalnih prediktora (npr. individualne karakteristike, obitelj, mediji, zajednica i sl.) koje nismo obuhvatili ovim istraživanjem.

\section{ZAKLJUČAK}

Rezultati ovog istraživanja u skladu su s prijašnjim istraživanjima kod nas (Sušac i sur., 2012; Velki, 2012a) i u svijetu (Olweus, 1998, 2010). Vršnjačkim i školskim prediktorima najbolje smo uspjeli objasniti tjelesno nasilno ponašanje vršnjaka i verbalnu vršnjačku viktimizaciju. Ipak, velik dio (oko 70\%) varijance vršnjačkoga nasilja i viktimizacije ostaje neobjašnjen. Buduće studije trebale bi uzeti u obzir i druge potencijalne prediktore, npr. obiteljske (način odgoja djece, zlostavljanje i zanemarivanje djece) i individualne karakteristike (npr. empatija i impulzivnost), kao i reprezentativnost uzorka te primjenu višestrukih metoda u planiranju i provođenju istraživanja. 
Ahmed, E. i Braithwaite, V. (2004). Bullying and victimization: Cause for concern for both families and schools. Social Psychology of Education, 7(1), 35-54. doi:10.1023/B:SPOE.0000010668.43236.60

Aluede, O., Adeleke, F., Omoike, D. i Afen-Akpaida, J. (2008). A review of the extent, nature, characteristics and effects of bullying behaviour in schools. Journal of Instructional Psychology, 35(2), 151-158.

Bagwell, C. L. i Coie, J. D. (2004). The best friendships of aggressive boys: Relationship quality, conflict management, and rule-breaking behavior. Journal of Experimental Chid Psychology, 88(1), 5-24. doi:10. 1016/j.jecp.2003.11.004

Barboza, G. E., Schiamberg, L. B., Oehmke, J., Korzeniewski, S. J., Post, L. A. i Heraux, C. G. (2009). Individual characteristics and the multiple contexts of adolescent bullying: An ecological perspective. Journal of Youth and Adolescence, 38(1), 101-121. doi:10.1007/s10964-0089271-1

Bukowski, W. M., Sippola, L. K. i Newcomb, A. F. (2000). Variations in patterns of attraction of same- and other-sex peers during early adolescence. Developmental Psychology, 36(2), 147-154. doi:10.1037/00121649.36.2.147

Buljan Flander, G., Ćorić Špoljarić, R. i Durman Marijanović, Z. (2007). Pojava nasilja među djecom s obzirom na spol, dob i prihvaćenost/odbačenost u školi. Društvena istraživanja, 16(1-2), 157-174.

Cillessen, A. H. N. i Mayeux, L. (2004). From censure to reinforcement: Developmental changes in the association between aggression and social status. Child Development, 75(1), 147-163. doi:10.1111/j.14678624.2004.00660.x

Cook, C. R., Williams, K. R., Guerra, N. G. i Kim, T. E. (2010). Variability in the prevalence of bullying and victimization: A cross-national and methodological analysis. U S. R. Jimerson, S. M. Swearer i D. L. Espelage (Ur.), Handbook of bullying in schools: An international perspective (str. 347-362). New York: Taylor \& Francis Group.

Dake, J. A., Price, J. H. i Telljohann, S. K. (2003). The nature and extent of bullying at school. Journal of School Health, 73(5), 173-180. doi:10.1111/j.1746-1561.2003.tb03599.x

Dijkstra, J. K., Lindenberg, S. i Veenstra, R. (2007). Same-gender and cross-gender peer acceptance and peer rejection and their relation with bullying and helping among preadolescents: Comparing predictions from gender-homophily and goal-framing approaches. Developmental Psychology, 43(6), 1377-1389. doi:10.1037/0012-1649.43.6. 1377

Espelage, D. L., Bosworth, K. i Simon, T. R. (2000). Examining the social context of bullying behaviors in early adolescence. Journal of Counseling \& Development, 78(3), 326-333. doi:10.1002/j.1556-6676.2000. tb01914.x

Espelage, D. L., Mebane, S. E. i Swearer, S. M. (2004). Gender differences in bullying: Moving beyond mean level differences. U D. L. Espelage i S. M. Swearer (Ur.), Bullying in American schools: A social-ecological perspective on prevention and intervention (str. 15-35). Mahwah, NJ: Erlbaum. 
DRUŠ. ISTRAŽ. ZAGREB GOD. 22 (2013), BR. 1, STR. $101-120$

VELKI, T., VRDOLJAK, G.: ULOGA NEKIH..
Farmer, T. W., Leung, M. C., Pearl, R., Rodkin, P. C., Cadwallader, T. W. i Van Acker, R. (2002). Deviant or diverse peer groups? The peer affiliations of aggressive elementary students. Journal of Educational Psychology, 94(3), 611-620. doi:10.1037/0022-0663.94.3.611

Farrington, D. P. (1997). Early prediction of violent and non-violent youthful offending. European Journal on Criminal Policy and Research, 5(2), 51-66. doi:10.1007/BF02677607

Hanish, L. D., Kochenderfer-Ladd, B., Fabes, R. A., Martin, C. L. i Denning, D. (2004). Bullying among young children: The influence of peers and teachers. U D. L. Espelage i S. M. Swearer (Ur.), Bullying in American schools: A social-ecological perspective on prevention and intervention (str. 141-159). Mahwah, NJ: Lawrence Erlbaum Associates.

Harel-Fisch, Y., Walsh, S. D., Fogel-Grinvald, H., Amitai, G., Pickett, W., Molcho, M., Due, P., Gaspar de Matos, M. i Craig, W. (2011). Negative school perceptions and involvement in school bullying: A universal relationship across 40 countries. Journal of Adolescence, 34(4), 639-652. doi:10.1016/j.adolescence.2010.09.008

Haselager, G. J. T., Hartup, W. W., van Lieshout, C. F. M. i Riksen-Walraven, J. M. A. (1998). Similarities between friends and nonfriends in middle childhood. Child Development, 69(4), 1198-1208. doi:10.1111/ j.1467-8624.1998.tb06167.x

Hodges, E. V. E., Boivin, M., Vitaro, F. i Bukowski, W. M. (1999). The power of friendship: Protection against an escalating cycle of peer victimization. Developmental Psychology, 35(1), 94-101. doi:10.1037/00121649.35.1.94

Kasen, S., Berenson, K., Cohen, P. i Johnson, J. G. (2004). The effects of school climate on changes in aggressive and other behaviors related to bullying. U D. L. Espelage i S. M. Swearer (Ur.), Bullying in American schools: A social-ecological perspective on prevention and intervention (str. 187-210). Mahwah, NJ: Erlbaum.

LaFontana, K. i Cillessen, A. H. N. (2002). Children's perceptions of popular and unpopular peers: A multimethod assessment. Developmental Psychology, 38(5), 635-647. doi:10.1037/0012-1649.38.5.635

Marini, Z. A., Dane, A. V. i Bosacki, S. L. (2006). Direct and indirect bully-victims: differential psychosocial risk factors associated with adolescents involved in bullying and victimization. Aggressive Behavior, 32(6), 551-569. doi:10.1002/ab.20155

McDermott, P. A. (1996). A nationwide study of developmental and gender prevalence for psychopathology in childhood and adolescence. Journal of Abnormal Child Psychology, 24(1), 53-66. doi:10.1007/BF0144 8373

Moffitt, T. E. (2005). Genetic and environmental influences on antisocial behaviors: Evidence from behavioral-genetic research. Advances in Genetics, 55, 41-104. doi:10.1016/S0065-2660(05)55003-X

Mouttapa, M., Valente, T., Gallaher, P., Rohrbach, L. A. i Unger, J. B. (2004). Social network predictors of bullying and victimization. Adolescence, 39(154), 315-335.

Mynard, H. i Joseph, S. (1997). Bully/victim problems and their association with Eysenck's personality dimensions in 8 to 13 year-olds. British Journal of Educational Psychology, 67(1), 51-54. doi:10.1111/j.20448279.1997.tb01226.x 
DRUŠ. ISTRAŽ. ZAGREB GOD. 22 (2013), BR. 1 STR. 101-120

VELKI, T., VRDOLJAK, G.: ULOGA NEKIH...
Nansel, T. R., Overpack, M., Pilla, R. S., Ruan, W. J., Simons-Morton, B. i Scheidt, P. (2001). Bullying behaviors among US youth. Prevalence and association with psychosocial adjustment. JAMA, 285(16), 2094-2100. doi:10.1001/jama.285.16.2094

Newman, R. S., Murray, B. i Lussier, C. (2001). Confrontation with aggressive peers at school students' reluctance to seek help from the teacher. Journal of Educational Psychology, 93(2), 398-410. doi:10.1037/ 0022-0663.93.2.398

Olweus, D. (1998). Nasilje među djecom u školi: što znamo $i$ što možemo učiniti. Zagreb: Školska knjiga.

Olweus, D. (2010). Understanding and researching bullying: Some critical issues. U S. R. Jimerson, S. M. Swearer i D. L. Espelage (Ur.), Handbook of bullying in schools: An international perspective (str. 9-33). New York: Taylor \& Francis.

Olweus, D. i Limber, S. (1999). The bullying prevention program. U D. S. Elliott (Ur.), Blueprints for violence prevention (str. 1-79). Boulder, CO: Regents of the University of Colorado.

Parkhurst, J. T. i Hopmeyer, A. G. (1998). Sociometric popularity and peer-perceived popularity. Two distinct dimensions of peer status. The Journal of Early Adolescence, 18(2), 125-144. doi:10.1177/027243169 8018002001

Pellegrini, A. D., Bartini, M. i Brooks, F. (1999). School bullies, victims, and aggressive victims: Factors relating to group affiliation and victimization in early adolescence. Journal of Educational Psychology, 91(2), 216-224. doi:10.1037/0022-0663.91.2.216

Pellegrini, A. D. i Long, J. D. (2002). A longitudinal study of bullying, dominance, and victimization during the transition from primary school through secondary school. British Journal of Developmental Psychology, 20(2), 259-280. doi:10.1348/026151002166442

Profaca, B., Puhovski, S. i Luca Mrđen, J. (2006). Neke karakteristike pasivnih i provokativnih žrtava nasilja među djecom. Društvena istraživanja, 15(3), 575-590.

Rajhvajn Bulat, L. i Ajduković, M. (2012). Obiteljske i psihosocijalne odrednice vršnjačkog nasilja među mladima. Psihologijske teme, 21(1), 167-194.

Rigby, K. (2002). A meta-evaluation of methods and approaches to reducing bullying in pre-schools ane early primary school in Australia. Canberra: Attorney-General's Department.

Smith, P. K. i Slonje, R. (2010). Cyberbullying: The nature and extent of a new kind of bullying, in and out of school. U S. R. Jimerson, S. M. Swearer i D. L. Espelage (Ur.), Handbook of bullying in schools: An international perspective (str. 249-262). New York, Taylor \& Francis Group.

Sušac, N., Rimac, I. i Ajduković, M. (2012). Epidemiološko istraživanje nasilja među djecom. Rad prikazan u sklopu nacionalne konferencije Raširenost nasilja nad djecom u obitelji i među vršnjacima, 22. i 23. ožujak, 2012., Zagreb, Hrvatska.

Velki, T. (2010). Pojavnost nasilja među srednjoškolcima. U V. Kolesarić (Ur.), Zbornik radova sa skupa Nasilje nad djecom i među djecom (2008) (str. 267-282). Osijek: Filozofski fakultet Sveučilišta Josipa Jurja Strossmayera u Osijeku. 
DRUŠ. ISTRAŽ. ZAGREB GOD. 22 (2013), BR. 1, STR. $101-120$

VELKI, T., VRDOLJAK, G.: ULOGA NEKIH...
Velki, T. (2012a). Provjera ekološkoga modela dječjega nasilničkoga ponašanja prema vršnjacima. (Neobjavljena doktorska disertacija). Sveučilište u Zagrebu, Filozofski fakultet, Zagreb.

Velki, T. (2012b). Uloga nekih obiteljskih čimbenika u pojavi nasilja među djecom. Psihologijske teme, 21(1), 29-60.

Williams, K. R. i Guerra, N. G. (2007). Prevalence and predictors of Internet bullying. Journal of Adolescent Health, 41(6), S14-S21. doi:10. 1016/j.jadohealth.2007.08.018

\section{The Role of Some Peer and School Variables in Prediction of Peer Violence}

Tena VELKI

Faculty of Teacher Education, Osijek

Gabrijela VRDOLJAK

Faculty of Humanities and Social Sciences, Osijek

The aim of this research was to examine potential peer and school predictors of peer violence on the sample of Croatian primary school children. While controlling for gender, age and school success, the aim was to ascertain which of the selected peer predictors (number of friends, social status and peer acceptance) and school predictors (school climate and safety in the school surroundings) predict overall, verbal and physical peer violence, and overall, verbal and physical victimization. 262 pupils from 5th to 8th grades of primary school participated in the research. The pupils completed the Questionnaire of violence among school children, School climate questionnaire and the sociometric procedure. Results have shown that the selected predictors explain physical peer violence best (31.9\%), then verbal victimization (33\%). After controlling for individual variables, the number of friends, social status and school climate were significant predictors of peer violence, while the number of friends, social status, peer acceptance and school climate were significant predictors of peer victimization. The research has shown that peer and school variables have a significant influence in predicting peer violence and victimization. However, a significant part of peer violence and victimization variance remains unexplained. Thus, future research should examine some other variables, such as the family and media, as potential predictors.

Keywords: peer violence, school predictors, peer predictors 